Research Article

\title{
Customers' Perspectives on the Nepalese Cellular Telecommunications Services' Technological and Innovation Capabilities

\author{
Rewan Kumar Dahal
}

Faculty of Management, Tribhuvan University, Nepal

Article Information
Received: 31 December 2021
Revised version received: 21 January 2022
Accepted: 23 January 2022
Published: 28 January 2022
Cite this article as:
R.K. Dahal (2022) Int. J. Soc. Sc. Manage. 9(1): 41 -
47. DOI: $10.3126 / i j s s m . v 9 i 1.42663$
*Corresponding author
Rewan Kumar Dahal,
Faculty of Management, Tribhuvan University,
Nepal.
Email: rewan.dahal@ ncc.tu.edu.np
Peer reviewed under authority of IJSSM
O2022 IJSSM, Permits unrestricted use under the
CC-By-NC license.
OPEN O ACCESS
This is an open access article \& it is licensed under a
Creative Commons Attribution Non-Commercial 4.0
International
(https://creativecommons.org/licenses/by-nc/4.0/)
Keywords: Competitive

\section{Article Information}

Received: 31 December 2021

Revised version received: 21 January 2022

\section{Cite this article as:}

R. Dahal (2022) Int. J. Soc. Sc. Manage. 9(1): 41

\section{*Corresponding author}

Nepal.

Peer reviewed under authority of IJSSM

(C)2022 IJSSM, Permits unrestricted use under the CC-By-NC license.

\section{Keywords: Competitive environment; performance}

\begin{abstract}
The extent of technological capabilities (TCs) and innovative capabilities (ICs) to which service organizations like cellular telecommunications assist to enhance organizational effectiveness (OE) in the Nepalese context needs to be explored. The study's objective was to assess the Nepalese cellular telecommunication (NCT) industry's technological and innovation capabilities from customers' perspectives. The study's outcomes were based on survey data gathered from 385 cell phone users of the Nepalese cellular telecommunication industry (NCTI). The survey had 18 inquiries, and its reliability, validity, and common method bias were tested accordingly. The NCTI's technological and innovative capabilities were analyzed through the lens of four observed TCs' variables and five observed ICs' variables. The latent measures - TCs and ICs were found to positively and significantly affect the OE. The study's outcomes would provide a meaningful understanding and offer valuable information regarding the $\mathrm{OE}$ measurement system.
\end{abstract}

\section{JEL Classification:}

L25 Firm Performance: Size, Diversification, and Scope

L84 Personal, Professional, and Business Services

M41 Accounting

\section{Introduction}

Today's businesses are under pressure to increase efficiency and productivity in order to stay competitive. They must adapt to market changes by continuously improving their paradigms, products, practices, processes, systems, or services, as operational performance and organizational effectiveness (OE) are primarily dependent on technological and innovative capabilities (Tidd and Bessant, 2009). Service organizations, such as telecommunications, invest significant resources in technological innovation to re-engineer their products and processes, but the extent to which these technologies and innovations help organizations improve OE still needs to be explored (Armbruster et al., 2008). OE has been a significant concern for all types of organizations. Managers must know which factors influence the $\mathrm{OE}$ in order to take or begin appropriate measures. Defining, conceiving, and 
measuring the OE has always been challenging (Elrahman et al., 2020). They refer to the consequences of various organizational processes (Hussein et al., 2014), and outcomes are what the organizations desire (Morgan et al., 2009).

For firms functioning in highly competitive, inventive, and advanced technology environments, the use of financial measures-based performance systems alone is not sufficient to measure OE (Mat and Smith, 2014). Modern businesses need a multi-dimensional performance monitoring system to deliver more information to investors and other stakeholders. Service industries'- particularly the telecommunications - two most essential elements, as measured by various performance and effectiveness indicators, are technology and innovation. In today's competitive marketplace, products/services or businesses that incorporate technology advancements with innovative ideas stand out. Accordingly, the study seeks to notice: What do customers think of the technological and innovation capabilities of the NCTI for delivering OE? Organizational excellence has become a pressing necessity, particularly cellular telecommunication. Therefore, the study aims to assess the technological and innovation capabilities regarding the NCTI.

A firm's competitive advantage can be enhanced by gaining a better grasp of its stakeholders' expectations regarding organizational performance, as well as how new technologies and innovations can be introduced to improve the OE (Slack et al., 2009). OE can be improved by setting performance goals and benchmarks. Many companies are missing out on the benefits of technological innovation because they either don't measure performance or the performance metrics they measure don't fit the context (White, 1996). It is important to note that telecommunication services are a very creative industry in which rapid developments are made. Consequently, telecommunications firms are under constant pressure to offer innovative products more quickly, cheaply, and improved quality in today's globally competitive business environment (Din et al., 2016). In addition, the peculiarities of cellular telephony involve a unique interaction with the customer, which necessitates measuring the $\mathrm{OE}$ in a larger sense from the consumer's perspective. As a result, this is a relevant study in the Nepalese context, given the rapid growth of cell phone users.

\section{Literature Review and Hypotheses Development}

Numerous methods exist for assessing OE, as well as a wide range of measurement metrics, are available. It's challenging to identify a comprehensive body of literature to situate this subject because there are many different approaches to gauging technological and innovation capabilities (Rosenbusch et al., 2011). Instead of gathering capital, in today's knowledge-based economy, organizational growth is predominantly driven by innovative capacity, fueled by the correct information and technical externalities (Din et al., 2016). The world of technology is evolving at a breakneck speed, and the cellular telecommunication sector is no exception. Varela and del Rio (2003) found that technological advancements have a significant impact on marketing opportunities. Customers' preferences continually change, posing several challenges for any organization (Chen et al., 2009). Technological breakthroughs allow for the creation of previously unimaginable products and services (Huarng, 2011). New technologies provide business actors with new challenges and chances to provide customers with unique products/services to build long-term partnerships (Yeh and $\mathrm{Fu}, 2013$ ) and set them apart from their competitors (Saco and Goncalves, 2008).

Maintaining or improving the $\mathrm{OE}$ has been identified as one of the most crucial concerns facing the cellular telecommunications industry, with which many organizations are grappling. Network and service quality impact telecom service providers' organizational performance (Saha et al., 2016). Negi (2009) and Rahman et al. (2011) recognized network quality as important in determining overall organizational effectiveness. Signal quality and network coverage have been found to improve user satisfaction and the company's image (Woo and Fock, 1999). Service certification in telecommunications networks includes voice quality. Rapid resolution of voice faults improves service provider performance (Aire et al., 2004). Calls drop is one of the main performance measures for network operators. It is thought to have a direct impact on consumer satisfaction (Eljaam, 2005). Electronic customer relationship management (e-CRM) allows frequent client communication while maintaining database purity (O'Leary et al., 2004). The adoption of e-CRM improves organizational efficiency and has a direct impact on overall organizational performance (Kim-soon and Zulkifli, 2012).

Innovation is the process of transforming an idea or creation into a product or service that customers want and pays its providers well. New corporate practices, workplace regulation, decision-making, and new ways of dealing with external relations are introduced through innovation performance measures (Polder et al., 2010). Product/service innovation satisfies customers and improves business value by reducing risk (Dotzel et al., 2013). Innovation assesses customer needs and desires and meets them by enhancing customer benefits and OE (Zaefarian et al., 2017). The conversion of new technologies into processes has a significant impact on corporate performance and a firm's competitiveness (Anning-Dorson, 2016b). Service competitiveness in the telecommunications sector influences technological and inventive performance and 
allows service systems to be tailored to a specific client inside a given use-case, creating unique value for that customer (Anning-Dorson, 2016a). Companies employ competitive innovation to gain a competitive advantage by offering unique products, doing things better than competitors, or delivering superior, cheaper, and faster services (Aziz and Samad, 2016). Marketing innovation involves considerable modifications in product design, placement, packaging, distribution, communication, and promotion strategies to reduce transaction costs and improve organizational performance (Hassan et al., 2013). Organizations that adopt innovative practices will be better positioned in the market and can retain customers (Auken et al., 2008).

Based on the review of literature, the study has the following two hypotheses:

\section{H1: Technological capabilities positively and significantly} affect the $O E$.

H2: Innovation capabilities positively and significantly affect the $O E$.

\section{Materials and Methods}

In addressing the issues, the study took a quantitative approach which was based on a survey of customers in organizations affiliated with the NCTI. The study's intended populace consisted of all the global systems for mobile (GSM) customers of Nepal Telecom and Ncell. According to the management information system report of the Nepal telecommunication authority (July 2021), customers of the sample companies account for more than $94 \%$ of the NCT market share. The respondents for the survey were chosen through purposeful sampling from a pool of service providers, university students, and freelancers. A sample plan based on the recommendations of Bowerman et al. (2004) as well as Krejcie and Margan's (1970) generalized scientific guideline was utilized to collect the responses of 385 participants.

A standardized survey questionnaire was used to collect data from the respondents. The questionnaire included 18 questions about the respondents' demographic and general information (6), technological and innovation capabilities measurements (10), and OE measures (2). On a six-point Likert scale, respondents were asked to rate their responses to 12 questions about technology and innovative capabilities and the OE. The Likert scale was set at 1 to 6 , with 1 indicating strong disagreement and 6 indicating strong agreement. Five hundred fifty questionnaires were distributed in the Kathmandu valley during the 90-day period of June - August 2021 to conduct a field survey among service holders in various organizations, university students, and freelancers, and 385 properly filled-out responses were obtained and used.

\section{Result and Discussions}

The study assessed the reliability and validity to confirm the suitability of the constructs before assessing the hypothesized model. As per the recommendation of Nunnally (1993), the reliability of the constructs was measured using Cronbach's alpha ( $\alpha$ ). The value of alpha of the technological capabilities having five observed variables (VAR_7, 8, 9, 10, and 11) was 0.773 . The analysis found that the VAR_11 the company alters and provides me all information through SMS' required to delete because of higher the value of alpha 0.805 if the item was deleted. Therefore, VAR_11 was not relevant in the study and was deleted from the analysis. Similarly, the alpha value of the innovation capabilities with five observed variables (VAR_12, 13, 14, 15, and 16) was 0.767 . None of the items were found to delete at this construct. Therefore, reliability statistics promoted nine variables within two constructs for further analysis. As suggested by Fornell and Larcker (1981), the validity of the constructs was measured using average variance extracted (AVE) and composite reliability (CR). Accordingly, as Podsakoff et al. (2003) advised, the study analyzed the Harman single factor test to identify the incidence and extent of the common method bias (CMB). The summary of the results with recommended cut-off values was presented in Table 1.

The cut-off values for reliability, validity and CMB insights were all met. As a result, the variables/constructs investigated were trustworthy, valid, and CMB-free, allowing for future exploration. As per the sample framed, the respondents general and demographic were as: service holders (38.1 \%), university students (44.4\%), and freelancers (17.5\%); female (51.4\%) male (48.6\%); aged below 35 years $(68.1 \%)$ and aged above 35 years $(31.9 \%)$; from Nepal Telecom (50.1\%) and from Ncell (49.9\%). The study showed that $71.8 \%$ of cell phone users in Nepal used pre-paid SIM cards exclusively, $26.3 \%$ of customers used post-paid SIM cards, and $1.9 \%$ of customers used pre-paid and post-paid SIM cards. The study took $95 \%$ of respondents with at least five or more years of experience using cell phone services in Nepal.

Multiple regression was run with $\mathrm{OE}$ as the dependent variable TCs and ICs as the independent variables. The model summary is shown in Table 2, and the ANOVA (Analysis of Variance) result is shown in Table 3. Multiple correlations revealed that the adjusted $\mathrm{R}$ Square was fundamentally different from zero $(\mathrm{F}=115.424, \mathrm{p}>.000)$, indicating that the dependent variables accounted for 37.7 $\%$ of the variation in the arrangement of independent variables. Table 4 depicts the total evaluation model. 
Table 1: Reliability, Validity and Common Method Bias Statistics

\section{Latent Measures}

\begin{tabular}{|c|c|c|c|}
\hline Technological & Innovative & Organizational & Total \\
\hline Capabilities (TCs) & Capabilities (ICs) & Effectiveness (OE) & \\
\hline $\begin{array}{l}\text { Network and service } \\
\text { quality }\end{array}$ & $\begin{array}{l}\text { Product/service } \\
\text { innovation }\end{array}$ & $\begin{array}{l}\text { Overall technological } \\
\text { capabilities }\end{array}$ & \\
\hline \multirow{2}{*}{$\begin{array}{l}\text { Signal strength and } \\
\text { coverage }\end{array}$} & Process innovation & \multirow{5}{*}{$\begin{array}{l}\text { Overall innovation } \\
\text { capabilities }\end{array}$} & \\
\hline & Customization & & \\
\hline Voice quality & Competitive & & \\
\hline \multirow[t]{2}{*}{ Calls drop } & innovation & & \\
\hline & Marketing innovation & & \\
\hline
\end{tabular}

\begin{tabular}{|c|c|c|c|c|c|}
\hline \multirow{2}{*}{$\begin{array}{l}\text { No engaged } \\
\text { variables }\end{array}$} & \multirow[t]{2}{*}{4} & \multicolumn{2}{|c|}{5} & \multirow[b]{2}{*}{ Cut-off value } & \multirow[b]{2}{*}{ Recommended by: } \\
\hline & & & & & \\
\hline $\begin{array}{l}\text { Reliabilty } \\
\text { indicators: } \\
\text { Alpha }(\alpha)\end{array}$ & 0.805 & 0.767 & 0.702 & $\geq 0.70$ & Nunnally, 1993 \\
\hline \multicolumn{6}{|l|}{$\begin{array}{l}\text { Validity } \\
\text { indicators: }\end{array}$} \\
\hline CR & 0.801 & 0.834 & 0.701 & $\geq 0.70$ & $\begin{array}{l}\text { Fornell and Larcker, } \\
1981\end{array}$ \\
\hline AVE & 0.514 & 0.502 & 0.536 & $\geq 0.50$ & $\begin{array}{l}\text { Fornell and Larcker, } \\
1981\end{array}$ \\
\hline \multicolumn{6}{|c|}{ Common method bias indicator: } \\
\hline Harman $\mathrm{Si}$ & factor variance & 0.3816 & & $\leq 0.50$ & Cho and Lee, 2012 \\
\hline
\end{tabular}

Table 2: Model Summary

\begin{tabular}{c|c|c|c}
\hline \multicolumn{1}{c|}{ R } & R Square & Adjusted R Square & Std. Error of the Estimate \\
\hline 0.614 & 0.377 & 0.373 & 0.714 \\
\hline Predictors: & (Constant), TCs, ICs \\
Dependent variable: & OE
\end{tabular}

Table 3: ANOVA Result

\begin{tabular}{l|c|c|c|c|c}
\hline & Sum of Squares & df & Mean Square & F & Sig. \\
\hline Regression & 117.623 & 2 & 58.812 & 115.424 & 0.000 \\
Residual & 194.640 & 382 & 0.510 & & \\
\hline Total & 312.264 & 384 & & & \\
\hline
\end{tabular}

Dependent variable: $\mathrm{OE}$

Predictors: $\quad$ (Constant), TCs, ICs 
Table 4: Regression Coefficients

\begin{tabular}{|c|c|c|c|c|c|c|c|}
\hline \multirow[b]{2}{*}{ Model } & \multicolumn{2}{|c|}{ Unstandardized Coefficients $^{a}$} & \multirow{2}{*}{\begin{tabular}{|c|} 
Standardized coefficients \\
Beta
\end{tabular}} & \multirow{2}{*}{ t-statistics } & \multirow[b]{2}{*}{ Sig. } & \multicolumn{2}{|c|}{ Variance Observations } \\
\hline & $\mathbf{B}$ & St. Error & & & & $\begin{array}{l}\text { Inflation } \\
\text { Factor }\end{array}$ & $\begin{array}{l}\text { on the } \\
\text { hypotheses }\end{array}$ \\
\hline (Constant) & 1.070 & 0.208 & & 5.139 & 0.000 & & - \\
\hline TCs & 0.177 & 0.043 & 0.179 & 4.123 & 0.000 & 1.159 & Accepted \\
\hline ICs & 0.592 & 0.049 & 0.524 & 12.060 & 0.000 & 1.159 & Accepted \\
\hline
\end{tabular}

a. Dependent variable: $\mathrm{OE}$

In this study, it has been demonstrated that the independent variables are different and contribute significantly to the $\mathrm{OE}$ of the NCTI. In this case, multicollinearity was not an issue because the measured variance inflation factor (VIF) values were not greater than four, as Hair et al. (2010) indicated.

The NCTI's technological and innovative capabilities were analyzed through the lens of five different variables each. One of these variables, regarding TCs (VAR_11_e-CRM), was not retained in the study; however, it was significant in the earlier studies (such as Kim-soon and Zulkifli, 2012; O'Leary et al., 2004). The latent measure TCs was examined from four observed variables: network and service quality $(\beta=0.685, p<0.01)$; signal strength and coverage $(\beta=0.749, \mathrm{p}<0.01)$; voice quality $(\beta=0.774, \mathrm{p}$ $<0.01)$; and calls drop $(\beta=0.653, \mathrm{p}<0.01)$ that directly influence OE. Technology facilitates innovation in competitive markets (Sood and Tellis, 2009). In consistent with the past studies (like Eljaam, 2005; Khan and Afsheen, 2012; Rahman et al., 2011; Saha et al., 2016), the study confirms that network and service quality, signal strength and coverage, voice quality, and calls drops to have significant influence to choose the cell phone operators as the service provider. That means cell phone operators must ensure good and robust TCs to please their subscribers. The fact that the TCs has emerged as one of the main constructs to measure $\mathrm{OE}$ demonstrates the strategic role.

To get a sense of the latent measure ICs, the study looked at the five observed variables: product/service innovation $(\beta=$ $0.791, \mathrm{p}<0.01)$; process innovation $(\beta=0.686, \mathrm{p}<0.01)$; customization $(\beta=0.675, p<0.01)$; competitive innovation $(\beta=0.772, p<0.01)$; and marketing innovation $(\beta=0.662$, $\mathrm{p}<0.01)$. Service innovation influences customer satisfaction and retention (Salunke et al., 2013). In order to remain competitive and meet the needs of customers, a business must constantly innovate its processes. Enhancing a company's competitive edge through customization is viable (Prahalad and Ramaswamy, 2004). By implementing new ideas and technology, companies can set themselves apart from the competition and improve their products and services to remain competitive. Customer satisfaction and competitive advantage are the primary goals of marketing innovation. The study found that the observed variables had a positive and substantial effect on the $\mathrm{OE}$, consistent with prior studies (such as Afriyie et al., 2018; Yildiz et al., 2014). In addition, the study supports Nam's (2014) study that ICs have a positive and significant impact on operational performance. Hence, innovation culture has been pronounced as a pre-condition for improving organizational, marketing, and managerial entrepreneurship in a competitive environment (Aksoy, 2017).

\section{Conclusion}

The study answered the research question 'how do customers view the NCTI's technological and innovation capabilities. It found that the TCs $(\beta=0.179, \mathrm{p}<0.01)$ and ICs $(\beta=0.524, p<0.01)$ positively and significantly affect the OE. It is believed that the resulting standardized weights of the latent measures will assist organizations in enhancing operational performance and obtaining a competitive advantage. Technologies encourage on delivery of valueadding products or services of exceptional quality, on time, and a competitive price. Organizations need high-quality information based on ICs to make various managerial decisions that can lead to better operational effectiveness. Studies of OE measurement systems span diverse fields, and methodological approaches differ substantially. This study cited a representative rather than striving to be exhaustive. The significant limitation is that the study employed only the quantitative survey with a structured questionnaire to acquire the essential information. The study's conclusions would provide useful guidance in understanding key driving variables of technological and innovative capabilities and offer meaningful information regarding strategic areas of the OE measurement system.

\section{References}

Afriyie S, Du J, Appiah K and Musah AAI. (2018) The nexus between types of innovation and marketing performance of SMEs in an emerging economy. International Review of Management and Marketing 8(6): 78-92. DOI: https://doi.org/10.32479/irmm.7042

Aire ET, Maharaj BT and Linde LP (2004) Implementation considerations in a SIP-based secure voice over IP network. In: Proceedings of the 7th AFRICAN, Botswana, Africa. Pages 167-172. 
Aksoy H (2017) How do innovation culture, marketing innovation, and product innovation affect the market performance of small and medium-sized enterprises (SMEs)? Technology in Society 51: 133-141. DOI: https://doi.org/10.1016/j.techsoc.2017.08.005

Anning-Dorson T (2016a) Interactivity innovations, competitive intensity, customer demand, and performance. International Journal of Quality and Service Sciences 8(4): 536-554.

Anning-Dorson T (2016b) Organizational culture and leadership as mediators of service innovation and firm competitiveness: A study of an emerging economy. International Journal of Innovation Management 20(7): 129.

Armbruster H, Bikfalvi A, Kinkel S and Gunter L (2008) Organizational innovation: The challenge of measuring non-technical innovation in large-scale surveys. Technovation 28(2): 644-657.

Auken HV, Madrid-Guijarro A, and Garcia-Perez-de-Lema D (2008) Innovation and performance in Spanish manufacturing SMEs. International Journal of Entrepreneurship and Innovation Management 8(1): 3656.

Aziz NNA and Samad S (2016) Innovation and competitive advantage: Moderating effects of firm age in foods manufacturing SMEs in Malaysia. Procedia Economics and Finance 35: 256-266.

Bowerman BL, O'Connell RT, and Orris JB (2004) Essential business statistics (3rd ed.). McGraw-Hill, New York.

Chen Y-S, Lin M-JJ and Chang C-H (2009) The positive effects of relationship learning and absorptive capacity on innovation performance and competitive advantage in industrial markets. Industrial Marketing Management 38(2):

152-158.

http://dx.doi.org/10.1016/j.indmarman.2008.12.003

Cho YJ and Lee JW (2012) Performance management and trust in supervisors. Review of Public Personnel Administration 32(3): 236-259. DOI: https://doi.org/10.1177/0734371X11421496

Din MU, Mangla, IU and Jamil, M (2016) Public policy, innovation, and economic growth: An economic and technological perspective on Pakistan's telecom industry. The Lahore Journal of Economics 21: 369-391.

Dotzel T, Shankar V and Berry LL (2013) Service innovativeness and firm value. Journal of Marketing Research 50(2): 259-276. DOI: http://dx.doi.org/10.1509/jmr.10.0426

Eljaam B (2005) Customer satisfaction with cellular network performance: Issues and analysis (unpublished doctoral dissertation). Iowa State University, United States.

Elrahman A, El-Borsaly A and Hassan S (2020) The impact of service quality on organizational performance in the mobile telecommunications sector in Egypt. Proceedings on Engineering Sciences 2(1): 93-104. DOI: 10.24874/PES02.01.010
Fornell C and Larcker DF (1981) Evaluating structural equation models with unobservable variables and measurement error. Journal of Marketing Research 18(1): 39-50.

Hair JF, Black WC, Babin BJ and Anderson RE (2010) Multivariate data analysis: A global perspective (7th ed.). Prentice-Hall.

Hassan MU, Shaukat S, Nawaz MS and Naz S (2013) Effects of innovation types on firm performance: An empirical study on Pakistan's manufacturing sector. Pakistan Journal of Commerce and Social Sciences 7(2): 243-262.

Huarng KH (2011) A comparative study to classify ICT developments by economies. Journal of Business Research 64(11): 11741177.

Hussein N, Mohamad A, Noordin F and Ishak NA (2014) Learning organization and its effect on organizational performance and organizational innovativeness: A proposed framework for Malaysian Public Institutions of Higher Education. ProcediaSocial and Behavioral Sciences 130: 299-304.

Khan S and Afsheen S (2012) Determinants of customer satisfaction in the telecom industry - A study of telecom industry Peshawar KPK Pakistan. Journal of Basic and Applied Scientific Research 2(12): 12833-12840.

Kim-soon N and Zulkifli MF (2012) The impact of electronic customer relationship management (e-CRM) on the business performance of the small company. Journal of Engineering and Technology 3(12): 139-153.

Krejcie R and Morgan D (1970) Determining sample size for research activities. Educational and Psychological Measurement 30: 607-610.

Mat TZT and Smith M (2014) The impact of changes in environment and AMT on management accounting practices and organizational strategy, structure, and performance. Journal of Applied Management Accounting Research 12(1): 55-82.

Morgan NA, Vorhies DW and Mason CH (2009) Market orientation, marketing capabilities, and firm performance. Strategic Management Journal 30(8): 909-920.

Nam VH (2014) The roles of human and social capital in the development of manufacturing SMEs in Vietnam. Journal of Economic Development 16(1): 5-22. https://doi.org/10.33301/2014.16.01.01

Negi R (2009) Determining customer satisfaction through perceived service quality: A study of Ethiopian mobile users. International Journal of Mobile Marketing 4(1): 3138.

Nepal Telecommunication Authority (July 2021). Management information system report, 140(188): 1-10.

Nunnally JC (1993) Psychometric theory (3rd ed.). McGraw-Hill, New York.

O'Leary C, Rao S and Perry C (2004) Improving customer relationship management through database/internet marketing. European Journal of Marketing 38(3/4): 338-354.

Podsakoff PM, MacKenzie CB, Lee J-Y and Podsakoff NP (2003) Common method biases in behavioral research: A critical 
review of the literature and recommended remedies. Journal of Applied Psychology 88(5): 879 - 903. DOI: 10.1037/0021-9010.88.5.879

Polder M, Leeuwen GV, Mohnen P and Raymond W (2010) Product, process and organizational innovation: Drivers, complementarity and productivity effects. CIRANO Scientific Publications, 2010s-28. http://dx.doi.org/10.2139/ssrn.1626805

Prahalad CK and Ramaswamy V (2004) Co-creation experiences: The next practice in value creation. Journal of Interactive Marketing 18(3): 5-14.

Rahman S, Haque A and Ahmad M (2011) Choice criteria for mobile telecom operator: Empirical investigation among Malaysian customers. International Management Review 7(1): 50-57.

Rosenbusch N, Brinckmann J and Bausch A (2011) Is innovation always beneficial? A meta-analysis of the relationship between innovation and performance in SMEs. Journal of Business Venturing 26: 441-457.

Saco MR and Goncalves PA (2008) Service design: An appraisal. Design Management Review, 19(1): 10-19.

Saha NK, Islam MR and Hoque AU (2016) Factors affecting customers' satisfaction of mobile phone subscribers: An empirical study on the mobile telecommunication industry in Bangladesh. International Journal of Business and Management 11(6): 252-261.

Salunke S, Weerawardena J and McColl-Kennedy JR (2013) Competing through service innovation: The role of bricolage and entrepreneurship in project-oriented firms. Journal of Business Research 66(8): 1085-1097.
Slack N, Chambers S and Johnston R (2009) Operations management ( $4^{\text {th }}$ ed). Prentice-Hall/Financial Times, Harlow.

Sood A, and Tellis GJ (2009) Do innovations really pay off? Total stock market returns to innovation. Marketing Science 28(3): $442-456$.

Tidd J and Bessant J (2009) Managing innovation. John Wiley and Sons, Hoboken - NJ.

Varela JA and del Río M (2003) Market orientation behavior: An empirical investigation using MARKOR. Marketing intelligence and Planning 21(1): 6-15.

White G (1996) A survey and taxonomy of strategy-related performance measures for manufacturing. International Journal of Operations and Production Management 16(3): 42-61.

Woo KS and Fock HKY (1999) Customer satisfaction in the Hong Kong mobile phone industry. The Service Industries Journal 19(3): 162-174.

Yeh S-P and Fu H-W (2013) Effects of service innovation on customer satisfaction in the recreation industry. International Journal of Applied Mathematics and Statistics 38(8): 107116.

Yıldız S, Baştürk F and Boz, İT (2014) The effect of leadership and innovativeness on business performance. ProcediaSocial and Behavioral Sciences 150: 785-793.

Zaefarian G, Forkmann S, Mitręga M and Henneberg SC (2017) A capability perspective on relationship ending and its impact on product innovation success and firm performance. Long Range Planning 50(2): 184-199. 